\title{
Evaluating Darwin's Book on the Descent of Man
}

\author{
Egbert Leigh ${ }^{*}$ (1)
}

\begin{abstract}
This is a review of A Most Interesting Problem: What Darwin's Descent of Man Got Right and Wrong about Human Evolution, edited by Jeremy DeSilva. The book has ten chapters, the first seven evaluating and updating the seven chapters of The Descent of Man, the eighth outlining Darwin's theory of sexual selection, the ninth criticizing Darwin's view of how sexual selection shaped human racial divergence, and the tenth summarizing hominin diversification.

Keywords: Human ancestry, Hominin diversification, How intelligence enables morality, Interdependence, Group selection and morality, Selection by reputation, Social Darwinism, Intertribal competition, Colonialism, Races and racism, Darwin's social prejudices
\end{abstract}

\section{Book details}

Title: A Most Interesting Problem: What Darwin's Descent of Man Got Right and Wrong about Human Evolution.

ISBN: ISBN 978-0-691-19114-0,

Number of pages:

Edited by:

Published by:
Pp. xxvii +249 ,

Jeremy M. DeSilva,

Princeton, NJ: Princeton University Press; 2021.

\section{Book Review}

Darwin's (1871) Descent of Man and Selection in Relation to Sex appeared 150 years ago. To commemorate this anniversary, Jeremy DeSilva has edited a volume with an excellent introduction by Janet Browne and ten essays evaluating how well Darwin answered his questions and outlining what has been learned since. The first seven essays deal with the seven chapters of the Descent of Man, the eighth outlines how sexual selection works, the

*Correspondence: bufotyphonius@gmail.com Baltimore, MD, USA

ninth considers chapters 19 and 20 on how sexual selection affected human evolution and racial diversification, and the tenth summarizes fossil and DNA evidence on the rise and fall of hominin diversity.

Janet Browne, who wrote a fine two-volume biography of Darwin, introduces the book. Her remarks on p. 3 reflect her introduction's tone: "[The Descent of Man's] intellectual breadth was astonishing. And even though the format now seems archaic, the style of reasoning overly anecdotal, and the social views regrettably typical of a nineteenth-century British gentleman, Darwin's central remarks retain, even today, their power to explain aspects of the natural world," She shows how propitious Darwin's family background, and even his times, were to his undertaking, and how, even so, he delayed writing about human evolution until colleagues prepared the ground for him. She suggests that Darwin's exposure to both Fuegians educated in England and those in their native habitat was a salutary shock. She outlines what the Descent covered, including his controversial views on human cultural progress and the development of civilization, the role of sexual selection in human sexual differentiation and the evolution of human races, and his fear that the uneducated, assumed to be less intelligent, might be outreproducing the more able and intelligent. Darwin believed in a hierarchy of the races, not only in original author(s) and the source, provide a link to the Creative Commons licence, and indicate if changes were made. The images or other third party material in this article are included in the article's Creative Commons licence, unless indicated otherwise in a credit line to the material. If material is not included in the article's Creative Commons licence and your intended use is not permitted by statutory regulation or exceeds the permitted use, you will need to obtain permission directly from the copyright holder. To view a copy of this licence, visit http://creativecommons.org/licenses/by/4.0/. The Creative Commons Public Domain Dedication waiver (http://creativeco mmons.org/publicdomain/zero/1.0/) applies to the data made available in this article, unless otherwise stated in a credit line to the data. 
social complexity and technological development, but in innate mental capacity. He showed that larger, more technological societies were replacing tribal ones. She thinks that these views served to justify "Social Darwinism's" promotion of unbridled, unregulated competition among individuals and societies as right and good. Hers is a very fair introduction to the book's contents.

In the first chapter, the biological anthropologist Alice Roberts lays out Darwin's comparative approach to demonstrating the community of ancestry of human beings with other animals from the similarity of amphibian, reptile, bird and mammal skeletons, the anatomical similarities of all vertebrates, the greater similarity of embryos relative to adults, and human vestiges of structures useful in other animals. Although some of Darwin's human "vestiges" have turned out to be adaptive, the soundness of Darwin's approach has been abundantly vindicated by the basic biochemical similarity of all life (Monod 1972, pp. 102ff).

Next, a neurobiologist, Suzana Herculano-Houzel, considers what we know about the mental capacities of human beings and other mammals. She does not start as Darwin did by comparing behaviors enabled by human mental capacities-love, memory, attention, curiosity, imitation, reason (Darwin 1871, p. i.105), imagination, tool use and aesthetic sense (Darwin 1871, pp. i. 46, 51 and 63)-with those of other mammals, although she gives a brief summary of these comparisons on p. 59. Lorenz (1978, see especially chapter 7 on the roots of conceptual thought) had already put Darwin's approach to good use. Instead, she starts from the basic similarity of all vertebrate brains. For lack of space, she gives less detail on the neural basis of different mental capacities than does Changeux (2008), only a brief summary of the functions of various parts of the human brain (pp. 51-53). Instead, she shows that in all vertebrates, neurons are arranged in loops, whereby a sensory neuron's signal can lead to the stimulation of a motor neuron, whose effects in turn stimulate the sensory neuron (pp. 49-50). Moreover, the nervous system exhibits spontaneous activity: it is not simply a stimulus-response (input-output) system like a computer. Finally, the brain has associative connections that allow varying degrees of complexity and flexibility in the behavior of different animals (pp. 50-53). She expects species with more cortical neurons to have greater mental capacity, which in turn allows more flexible and intelligent behavior (pp. 58-59). In primates, neuron size is constant, whereas in other mammals larger brains have larger neurons. Thus a human brain's cortex is half the size of an elephant's, but has three times as many neurons (pp. 57-58). Human brains are big primate brains with more cortical neurons allowing more intelligent behavior. Big brains consume abundant energy: only the ability to cook food, making it more nutritious and digestible, allowed human beings to evolve them (p. 57). Maximum life span, and age at sexual maturity, correlate more closely with number of cortical neurons than with body size or metabolic rate. This circumstance allows more intelligent animals greater opportunity for cultural transmission (pp. 60-61). This chapter is uncommonly full of new good ideas: Darwin would have loved it.

In chapter 3 the evolutionary anthropologist Brian Hare discusses Darwin's chapter on the origins of morality. He recognizes (pp. 80-81) that showing how the amoral process of natural selection can favor the evolution of morality is an astounding achievement. As Darwin did in his chapter on mental capacity, Hare here discusses the extent to which human beings share different rudiments of morality with bonobos and dogs-sympathy (female bonobos willingly share a feast of fruit with another, especially a stranger), reasoning (a male bonobo chased by angry females turns about, "cries wolf", making false alarm calls that create confusion amidst which he escapes), regret (making the wrong choice in what lever to press for food), and learning by imitation. Like Darwin, he finds that apes lack morality. He discusses the love of a dog for its master, and various animals' self-control (restraint of immediate desire in order to gain more later), which last he sees only in larger-brained animals. I find his examples less telling, on the whole, than those of Darwin or de Waal (2016, 2019). More significantly, Hare explains how selection among foxes for friendliness with human beings yielded animals that were not only friendly but had floppy ears, curly tails, shorter faces, smaller teeth and multicolored fur, just as happened when dogs evolved from wolves (pp. 74-75). Moreover, friendly foxes, like dogs but unlike wolves or chimpanzees, understand human signals such as pointing. This was a shocking illustration of genetic correlation. Hare, unlike Darwin, knows evidence of the effectiveness of selection for human bonding, which works by increasing levels of the hormone oxytocin. On the other hand, Darwin (pp. i. 75, 93) understood that what drove selection for social life and social instincts was interdependence among members of a social group, whose members must cooperate to bring down big prey or defend the group against competitors. Plato (Republic, Book I, 352c) realized long ago that members of a gang of thieves must treat each other justly and fairly if the gang is to survive, let alone function. Hare, however, never mentions the role of interdependence in the evolution of morality. As interdependence is not discussed in any other chapter, this book lacks a crucial element for discerning just what Darwin got right and wrong about human evolution. 
In chapter 4, the paleontologist Yohannes HaileSelassie endorses (p. 83) Darwin's argument that human beings, like other animals, are subject to natural selection. He then summarizes fossil evidence for the origin and diversification of hominins after their divergence from the chimpanzee-gorilla lineage. Early hominins $(6.5+\mathrm{Ma})$, Sahelanthropus, were facultatively bipedal and had shorter, blunter canines than chimps which, as Prum (2017, pp. 296-297) reasonably concluded, reflected reduced male dominance. Their brains, however, were chimp-sized, and they used no tools. The same was true for other hominins before 4.2 Ma. Australopithecus, which first appeared $4.2 \mathrm{Ma}$, were more bipedal, had larger molars and yet smaller canines, chimp-sized brains, and no tools. Australopithecus diversified during its $2+$ million-year tenure, and one species gave rise to the larger-brained genus Homo, perhaps $2.8 \mathrm{Ma}$, although the most convincing fossils come nearer $2 \mathrm{Ma}$. Homo erectus appeared $2 \mathrm{Ma}$, shortly after the smaller Homo habilis, which used tools. Homo erectus, which had larger brains but smaller molars than $H$. habilis, probably depended on cooked food and needed fire (Wrangham 2009), fashioned stone hand-axes and was probably using fire to cook food by $1 \mathrm{Ma}$ (p. 100). Homo erectus spread to the Caucasus 1.8 Ma, and onward to China and Java, giving rise among others to Neanderthals and Denisovans. Our species, Homo sapiens, with yet larger brains, appeared between 300,000 and 160,000 years ago. Both $H$. heidelbergensis, ancestral to H. sapiens, and Neanderthals were probably talking by 350,000 years ago (Jolly 1999, pp. 380-381). H. sapiens also spread through Eurasia, first interbreeding with, then replacing the Neanderthals and Denisovans. This series of fossils, unknown in Darwin's time, justified his claim that human beings evolved from smaller-brained primates and disproved his hypothesis that the hands "released" for other uses by bipedalism were immediately used for tool-making. Haile-Selassie's story of what these fossils reveal about the course of human evolution is useful and well told.

The first part of Darwin's chapter 5, on the mental and moral faculties of "primeval" human beings, is central to his theory of how morality evolved. The bioarchaeologist Kristina Killgrove's analysis of this chapter, whose focus was the second part on civilization, misses this theory's importance. I therefore review the theory and its current status before turning to her discussion. Darwin (1871, pp. i. 71-72, 159-161) considered intelligence necessary for morality, assumed that both varied heritably, and that since some tribes were always replacing others, tribes whose members were more intelligent, courageous and loyal to each other would win intertribal combats. Morality was strictly intratribal and favored the tribe, not the individual or species, suggesting that morality spread because it was crucial to tribal survival (Darwin 1971, pp. i. 93ff, 162). He saw that within-group selection favors selfishness, but that the tendency to help others from which one received help (as in chimps: de Waal 1997) and especially, helping those reputed for helpfulness, courage, and loyalty to other tribe members would counter this selection. Moreover, tribe members, being intelligent, would see that harmonious cooperation was essential for the tribe and its members to survive (Darwin 1871, p. i. 165). This argument is still considered valid, although communal punishment of non-cooperators also played a crucial role in the evolution of morality (Boehm 1997, 2012). Morality, however, is spread not only by intertribal conflict but by the need to cooperate to bring down big game or to pool knowledge on where to find food during severe drought (Boehm 2012). Differentially helping those of good repute stabilizes cooperation (Fehr and Fischbach 2003, Fehr 2004; Panchanathan and Boyd 2004), as does punishing noncooperators (Fehr and Gächter 2002).

Killgrove (pp. 109-115) gives a fair if sometimes uncomprehending account of Darwin's arguments, mentioning without comment his theory of how morality (which she calls altruism) evolved. Darwin misleadingly illustrated tribe replacing tribe by civilized nations replacing tribes (Darwin 1871, p. i. 160): but disease and vastly superior weaponry, factors irrelevant alike to morality and normal intertribal warfare, drove the victories of the conquistadors. She discusses Darwin's uncertainty whether the (unquestioned) duty to protect the weak and unfortunate leads to society's moral and intellectual decline. She did not mention Darwin's (1871, p. i. 169) acute remark that inequality is needed for civilization to develop and for science and technology to advance. In turn, Darwin failed to grasp that the extreme inequality civilization often imposes often leads to the cultural degradation of the underclass thus created.

Her tone changes, and she begins to stray from Darwin's chapter, on p. 115. She taxes Darwin with "patriarchal language" (correct usage at that time, and not necessarily exclusionary: in the King James version of the Bible Genesis 1:27 reads "So God created man... Male and female created he them"); his conflation of morality and religion (not evident in chapter 5); and his endorsement of colonialism (Darwin 1871, p. i. 179) (a flaw not crucial to his main contributions). On p. 116 she taxes Darwin with assuming that intelligence can be measured (Herculano-Houzel suggests a crude measure in chapter 2, pp. 58-59), and justly inveighs at length against the IQ concept, a twentieth century obsession irrelevant to Darwin's chapter 5. Finally, returning to the end of Darwin's chapter, she attacks the idea of progress in civilization. I find this attack odd: there is clearly a trend (which 
she recognizes: p. 122) during the last 11,000 years for civilizations with progressively larger scales of interdependence and diversity of occupations (Vermeij and Leigh 2012). The danger lies in associating morality with this progress, as Darwin did.

In chapter 6 the anthropologist John Hawks discusses how Darwin fit Homo into the classification-the phylogeny, for Darwin (1871, p. i. 188) believed classification should be genealogical (p. 126)-of other primates. Darwin (1871, pp. i. 189-191) argued that phylogeny was best inferred from useless or vestigial characteristics (pp. 139-141). Based on anatomical studies of Huxley, Owen and Mivart, Darwin (1871, p. i. 197) grouped Homo with the apes, but he had Homo diverge from the apes before other apes, including gibbons, diverged from each other (p. 127). Elsewhere (p. 133) Darwin (1871, p. i. 199) considered Homo most closely related to gorillas and chimpanzees, so he tentatively suggested that Homo first evolved in Africa. In Darwin's time, some assigned Homo its own kingdom, whereas Darwin (1871, pp. i. $186,195)$ thought that in a phylogenetic classification, Homo should rank as a family or subfamily. Now hominins, including Australopithecus, are ranked as a tribe; hominins plus chimpanzees and gorillas as the subfamily Homininae, and Homininae plus orangutans as the family Hominidae (p. 135). DNA has since shown Homo more closely related to chimps than Darwin thought (p. 137). Chapter 6 was perhaps Darwin's most "Copernican" moment: Copernicus ranked the earth as just another planet, Darwin ranked Homo as just another animal.

In chapter 7 the anthropologist Agustín Fuentes evaluates the Descent of Man's last chapter on "the races of man." Here Darwin concludes that Homo is a single monophyletic species and ranks the races as subspecies (pp. 147-149) which diverged thanks to long isolation on their respective continents (pp. 150-151). Darwin could not explain physical differences among the races without invoking sexual selection (p. 152). Despite his experiences with educated Fuegians and an African black he came to know (Darwin 1871, p. i. 232), he inferred (I think from contrasts in level of civilization) major racial differences in mental and moral capacity (pp. 148, 152). Darwin (1871, i. pp. 236-238) inferred competitive replacement of races from extinctions of tribes, languages and cultures. He inferred from the replacement or subordination of indigenous races by European colonists that the more civilized also won intertribal contests (p. 160). Darwin did not criticize this process, although it was cruel and immoral by his own standard (Darwin 1871 pp. i. 168-169), and might even have approved of it, an attitude Fuentes justly criticizes. Fuentes next summarizes current understanding. Human beings form a single species and subspecies, and races cannot be clearly and consistently distinguished. Human beings are identical over $>99 \%$ of their genome, and existing genetic variation is distributed widely and irregularly. Fuentes ends by asking whether Darwin was a racist. Judging by his beliefs, he must have been, although his remark that the "high cultures" of Mexico and Peru developed indigenously (Darwin 1871, p. i. 183) suggests limits to his racism. Darwin's friendship with Fuegians and an African black do not suggest racist behavior. Sadly, Darwin trusted published false "facts" and his wrong inferences therefrom over his personal experience. Fuentes here criticizes Darwin fairly and honorably, with no trace of meanness.

In chapter 8, Michael Ryan, who was the first to demonstrate sexual selection by female choice in a wild population (Ryan 1980) and who shared in the first demonstration of conflict between natural and sexual selection (Ryan et al. 1982), summarizes how sexual selection works and how it differs from natural selection. Darwin (1871, pp. i. 256-257) distinguished between natural selection, which adapts a population to its environment, and sexual selection, which is driven by who mates with an individual that will soon mate anyway. Sexual selection arises when more of one sex (usually male) than the other are ready to mate, so members of the former sex compete for mates (pp. 167-169). Darwin (1859, pp. 88-89) noted that this competition can take two forms: combat for matings, or competition to attract mates. Ryan notes (p. 171) that sometimes males that cannot obtain mates by combat or attraction do so by stealth (Warner et al. 1975; Emlen 1997). Wallace opposed the idea of sexual selection by female choice (p. 172). Now, however, no one denies sexual selection by female choice: they argue over why they choose as they do (pp. 174-176). The most likely alternatives are choosing mates with which they will have the most, the most fit, or the best caredfor offspring, or choosing mates by criteria evolved in other contexts, such as choosing food, ease of detection, or previously unrevealed aesthetic preferences. Ryan (pp. 178-180) then discusses the neural bases of perceptive abilities, aesthetic preferences, and responsiveness to these perceptions. His chapter is sound biology, well presented, delivered on the basis of considerable thought and experience. How well it helps one understand mate choice in human beings, the reader must decide.

In chapter 9, concerning Darwin's two chapters on the role of sexual selection in human sexual dimorphism and racial divergence, the anthropologist Holly Dunsworth opens (p. 183) with the most intemperate of this volume's attacks on Darwin: “This [chapter] is Darwin's begetting every caveman-inspired nugget of dating advice, every best-selling author's stance on innate gender roles, and every entertainer's sexist appeal to science." Invective is neither science nor coherent argument. The incoherent 
anachronism of Darwin dispensing dating advice inspired by barbaric cavemen arouses outright laughter.

Fortunately, the tone quickly improves. She provides (pp. 185-191) sound evidence for modern views on topics such as how natural (not sexual) selection accounts for latitudinal gradients in skin color, the paler skin of women, and why our ancestors lost their hair $>1 \mathrm{Ma}$. She makes no effort, however, to understand what led Darwin into error,

To learn what misled Darwin, two quotations are helpful. Darwin (1871, p. ii. 385) remarked that "False facts are highly injurious to the progress of science, for they often long endure," and J. B. S. Haldane (1932, p. 143) remarked that "[Darwin] was commonly right when he thought for himself, but often wrong when he took the prevailing views of his time... for granted." Darwin based his ideas about human sexual differences on the prevailing view that in primitive tribes, men had to fight to obtain and keep wives. If Boehm (2012) is right that we all descend from egalitarian tribes, the primary form of human social organization from 45,000 or even 200,000 to 15,000 years ago (Boehm 2012, pp. 35, 67, 160) Darwin's conclusions collapse: these egalitarian bands often punished aggressive appropriation of women by death. This collapse unhorses Darwin's claim that males are more intelligent because they had to be clever in winning a wife, leaving no reason to believe the odd and unreasonable doctrine of superior male intelligence (pp. 193-194).

Then she asserts the danger of striving for objectivity (pp. 194-195), which is indeed as impossible to attain (Nagel 1986) as perfection. Yet we must strive for both: seeking objectivity brings us out of our self-centeredness to focus on what we study.

Next, she rehashes old disputes. She seems to view competition vs cooperation as an either/or (pp. 195196), whereas evolution is an intricate interplay of competition and cooperation, the competitive process of natural selection often favoring complex social cooperation within species and mutualism among species (Jolly 1999, p. 4, Leigh and Ziegler 2019). She taxes Darwin with over-focus on competition, although he ends his chapter 3 with how civilization might extend morality (the basis of cooperation) beyond the tribe to the nation, and how morality and sympathy might be made universal (Darwin 1871, pp. 100-104).

Finally, what role should science play in moral decision-making? "What is" is a very poor predictor of "what ought to be." All the studies of gender roles in chimpanzees, bonobos and Neolithic agriculturalists cannot override the Golden Rule, whose importance to morality Darwin $(1871$, p. i. 106) so emphasized, that would forbid sexual (or racial) discrimination. I see little evidence that Darwin thought otherwise, but The Descent of Man is not a moralizing book. Science needs women: I think women like Alison Jolly $(1966,1985,1999)$ and Jane Goodall (1986) greatly improved primatology. The idea, however, hinted on p. 201 that hard (rigorous) science, as opposed to many of its practitioners, is hostile to women vanishes before the mathematician Emmy Noether, whose appointment to the Göttingen faculty was originally blocked by humanists despite the immense prestige of her advocate David Hilbert (Weyl 2012, p. 54) and Maryam Marzakhan, an Iranian mathematician who won the Fields medal in 2014. I have never heard female biologists complain about scientific rigor. Does this complaint reflect tension between biological and the more humanistic cultural anthropologists?

The science journalist Ann Gibbons opens chapter 10 by recounting a tour of Darwin's home, Down House and its grounds, by a few dozen archaeologists and anthropologists of the European Society of Human Evolution. This is a prelude to an imaginary dinner at Down House where the group's experts on paleontology and DNA phylogeny tell Darwin, one by one, what they and others have learned since 1871 about human evolution (pp. 207, 216). This is a rather moving retelling of chapter 4's story, even if Darwin doesn't get to say a word. The retelling brings out a few new twists. He is told that bonobos, not known in his time, are the modern ape most like ancestral hominins (p. 210); that, starting 3 or $4 \mathrm{Ma}$, there were always several coexisting species of hominins until $<50,000$ years ago; that $>5 \mathrm{Ma}$, early hominins slept in tree nests like chimpanzees to escape predators, ate fruit and seeds, and walked bipedally when on the ground; and that another species of Homo, $H$. neanderthalensis which later coexisted with our species, or a close relative of Neanderthals, appeared in Spain 430,000 years ago (p. 219). Darwin is also told how miniature species of Homo in the Philippines' Luzon Island and on Flores, that descended from $H$. erectus, confirmed his view that relatives of large animals on small islands were smaller. Darwin learns how techniques of extracting DNA from fossils revealed another species of Homo, the Denisovans, and showed that Homo sapiens interbred with Denisovans and Neanderthals before a new wave of $H$. sapiens erupting from Africa 70,000 years ago replaced all other surviving species of hominin (p. 220). Finally, Darwin learns that any pair of chimpanzee populations differ genetically far more than do any two human "races" (p. 221): there is no need to try to delineate human subspecies. The whole dinner is pleasant, cheerful, and a delight for Darwin. Gibbons has provided an uncommonly apt and reconciliatory coda to this turbulent volume.

For me, this book was quite a shock. I had expected passionate debate on the relative merits of Darwin's view of how morality and intelligence evolved from 
social instincts of group-living animals whose survival depended on cooperation, and the ideas of E. O. Wilson's (1975) Sociobiology, based on selfish genes, innate selfishness of human beings, and cooperation only among kin. Instead, amidst a wealth of enlightening information on human ancestry, the evolution of intelligence and morality, the rise and fall of hominin diversity, and the remarkable genetic homogeneity of modern humanity, I found impassioned accusations of Darwin's racism, sexism and reinforcement for "Social Darwinism."

One obvious lesson is that The Descent of Man is a complex book. Like the Bible, one can find, and emphasize, what one chooses to look for. Thus Darwin's (1871, pp. i. 168-169) assertion of our moral obligation to help the destitute and the disabled jumps to my eye; Darwin's (1871, p. ii. 403) assertion that humanity must remain subject to a severe struggle for existence if natural selection is to improve it, jumps to another's. Darwin's (1871, p. i. 101) vision of the attainment of universal sympathy for people of all nations and races, and to other animals (spiced with criticism of the ancient Romans for their inhumanity) jumps to my eye, his apparent acceptance (Darwin 1871, p. i. 160) of the replacement of indigenous tribes by technologically better-equipped colonists jumps to another's. The neurobiologist Changeux (2008, p. 66) sees in Darwin's morality an ethic totally contradictory to Spencer's "Social Darwinism" and its advocacy of unbridled competition, and notes that Spencer invented the idea of "Social Darwinism" in 1850, nine years before Darwin's Origin of Species. The moral philosopher Mary Midgley (2014) sees in Darwin's socially oriented morality an antidote to the rampant individualism of modern Western society, one facet of which is Spencer's "Social Darwinism." Midgley (2002) notes that in the 1880's Spencer was the best-selling philosopher in the US. On the other hand, Fuentes (p. 161) remarked of Darwin's chapter on the races of man that "To this day racist and nationalist/separatist ideologues use Darwin's words... as basis for their erroneous and intentionally hurtful and hateful positions and actions."

The second lesson implicate in this edited volume is that one must separate Darwinian wheat from Darwinian chaff (as Fuentes valiantly tried to do for the unpromising second half of Darwin's chapter, "On the Races of Man"), and not let the chaff bury the wheat. Darwin (1871) contains two parts, of which the second, Selection in Relation to Sex, is finally attaining the influence it deserves (Fisher 1930, pp. 129-141; West-Eberhard 1983, Prum 2017, Ryan 2018). Judging by this edited volume, Darwin's theory of the evolution of morality is still struggling for understanding, despite its demonstration that the blind mechanism of natural selection can bring forth as purposeful and immaterial a property as morality. This theory consists of two parts. First, morality is enabled by intelligence, for intelligence allows remembering past actions and assessing their consequences, and reason judges between conflicting aims and desires, favoring the most enduringly satisfying act, the one best for the group (Darwin 1871, pp. 88-91). Jolly's (1966) argument that the evolution of intelligence was prompted by social life fits perfectly with Darwin's theory. Darwin (1871, pp. i. 161-166) proposed that selection among groups, reinforced by sexual preference for those reputed for courage, loyalty and cooperativeness, was what favored morality. Nowadays, one would say that ensuring the cooperation needed to bring down big game influenced group selection more than did intertribal conflict, and that communal punishment of non-cooperators was a necessary ingredient that Darwin omitted (Boehm 2012). D. S. Wilson (2019) tried to complete this "Darwinian revolution" by showing how to fulfil Darwin's (1871, pp. i. 100-101) hope that "As man advances in civilization, and small tribes are united into larger communities, the simplest reason would tell each individual that he ought to extend his social instincts and sympathies to members of the same nation. This point being reached, there is only an artificial barrier to prevent his sympathies from extending to all races and nations." Darwin's moral vision is one that can inspire constructive social action.

In short, $A$ Most Interesting Problem is a stimulating book, but to derive full benefit from it, one must read the first five chapters and the concluding chapter of Darwin (1871).

\section{Abbreviations \\ Ma: Million years ago. \\ Acknowledgements \\ The author is most grateful to Revati Gireesh for her guidance through the process of electronic submission.}

\section{Authors' contributions}

Egbert Leigh read the book and wrote the book review. The author read and approved the final manuscript. All authors read and approved the final manuscript.

\section{Funding}

The author received no funding for preparing this book review.

Availability of data and materials

Not applicable.

\section{Declarations}

Competing interests

The author declares that he has no competing interests. 
Received: 11 June 2021 Accepted: 13 July 2021

Published online: 21 July 2021

\section{References}

Boehm C. Impact of the human egalitarian syndrome on Darwinian selection mechanics. Am Nat. 1997;150:S100-21.

Boehm C. Moral origins: the evolution of virtue, altruism and shame. New York: Basic Books; 2012

Changeux J-P. Du vrai, du beau, du bien: une nouvelle approche neuronal. Paris: Odile Jacob; 2008.

Darwin C. The origin of species by means of natural selection. London: John Murray; 1859

Darwin C. The descent of man and selection in relation to sex. 2 vol; London: John Murray; 1871

De Waal F. Good natured: the origins of right and wrong in humans and other animals. Cambridge, MA: Harvard University Press; 1997.

De Waal F. Are we smart enough to know how smart animals are? New York: W. W. Norton: 2016

De Waal F. Mama's last hug: animal emotions and what they tell us about ourselves. New York: W. W. Norton; 2019.

Emlen DJ. Alternative male reproductive tactics and male-dimorphism in the horned beetle Onthophagus acuminatus (Coleoptera: Scarabaeidae). Behav Ecol Sociobiol. 1997:44:335-41.

Fehr E. Don't lose your reputation. Nature. 2004;432:449-50.

Fehr E, Fischbacher U. The nature of human altruism. Nature. 2003;425:785-91. Fehr E, Gächter S. Altruistic punishment in humans. Nature. 2002:415:137-40.

Fisher RA. The genetical theory of natural selection. Oxford, UK: Oxford University Press; 1930.

Goodall J. The chimpanzees of Gombe: patterns of behavior. Cambridge, MA: Harvard University Press; 1986.

Haldane JBS. The causes of evolution. London: Longmans, Green \& Co.; 1932.

Jolly A. Lemur social behavior and primate intelligence. Science. 1966:153:501-6.

Jolly A. The evolution of primate behavior. 2nd ed. New York: MacMillan; 1985.

Jolly A. Lucy's legacy: sex and intelligence in human evolution. Cambridge, MA: Harvard University Press; 1999
Leigh EG Jr, Ziegler C. Nature strange and beautiful: how living beings evolved and made the earth a home. New Haven, CT: Yale University Press; 2019.

Lorenz K. Behind the mirror: a search for the natural history of human knowledge. New York: Harvest/HBJ; 1978.

Midgley M. Evolution as a religion. New York: Routledge; 2002

Midgley M. The solitary self: Darwin and the selfish gene. New York: Routledge; 2014

Monod J. Chance and necessity. New York: Alfred A. Knopf; 1971.

Nagel T. The view from nowhere. New York: Oxford University Press; 1986.

Panchanathan K, Boyd R. Indirect reciprocity can stabilize cooperation without the second-order freee-rider problem. Nature. 2004;432:499-502.

Prum RO. The evolution of beauty: how Darwin's forgotten theory of mate choice shapes the animal world —and us. New York: Doubleday; 2017.

Ryan MJ. Female mate choice in a neotropical frog. Science. 1980;209:523-5.

Ryan MJ. A taste for the beautiful: the evolution of attraction. Princeton NJ: Princeton University Press; 2018

Ryan MJ, Tuttle MD, Rand AS. Bat predation and sexual advertisement in a neotropical anyran. Am Nat. 1982;119:136-9.

Vermeij GJ, Leigh EG Jr. Natural and human economies compared. Ecosphere 2011:2(4);art. 39.

Warner RR, Robertson DR, Leigh EG Jr. Sex change and sexual selection. Science. 1975;190:633-8.

West-Eberhard MJ. Sexual selection, social competition and speciation. Q R Biol. 1983;58:155-83.

Weyl H. Levels of infinity: selected writings on mathematics and philosophy ( $P$. Pesic, ed.). Mineola NY: Dover; 2012.

Wilson DS. This view of life: completing the Darwinian revolution. New York: Pantheon; 2019.

Wilson EO. Sociobiology: the new synthesis. Cambridge, MA: Harvard University Press; 1975.

Wrangham RW. Catching fire: how cooking made us human. New York: Basic Books; 2009.

\section{Publisher's Note}

Springer Nature remains neutral with regard to jurisdictional claims in published maps and institutional affiliations.
Ready to submit your research? Choose BMC and benefit from:

- fast, convenient online submission

- thorough peer review by experienced researchers in your field

- rapid publication on acceptance

- support for research data, including large and complex data types

- gold Open Access which fosters wider collaboration and increased citations

- maximum visibility for your research: over 100M website views per year

At BMC, research is always in progress.

Learn more biomedcentral.com/submissions 